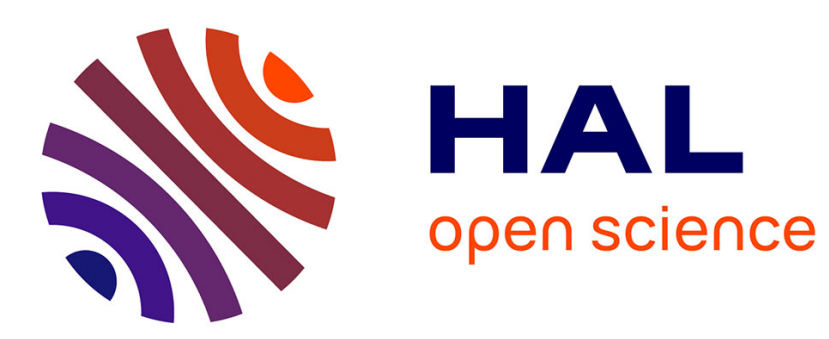

\title{
From knowledge to knowing, from boundaries to boundary construction
}

Claude Paraponaris, Martine Sigal

\section{To cite this version:}

Claude Paraponaris, Martine Sigal. From knowledge to knowing, from boundaries to boundary construction. Journal of Knowledge Management, 2015, 9 (5), pp.881-899. 10.1108/JKM-01-2015-0034 . halshs-01208528

\section{HAL Id: halshs-01208528 \\ https://shs.hal.science/halshs-01208528}

Submitted on 2 Oct 2015

HAL is a multi-disciplinary open access archive for the deposit and dissemination of scientific research documents, whether they are published or not. The documents may come from teaching and research institutions in France or abroad, or from public or private research centers.
L'archive ouverte pluridisciplinaire HAL, est destinée au dépôt et à la diffusion de documents scientifiques de niveau recherche, publiés ou non, émanant des établissements d'enseignement et de recherche français ou étrangers, des laboratoires publics ou privés. 


\section{From knowledge to knowing, from boundaries to boundary construction}

\section{Claude Paraponaris and Martine Sigal}

Aix Marseille University LEST CNRS,Aix en Provence, France.

This special issue is concerned with knowledge sharing and boundary crossing. Knowledge management is a constantly expanding field. Like any research area, it is shot through with complex questions. This is certainly the case with regard to boundaries, since they constitute both a bounding line that has to be crossed if the knowledge required for innovation is to be diffused and a form of protection for scientific and technological organisations and institutions.

The studies published in this special issue clearly illustrate this complexity, since they are concerned with processes such as learning, the dynamic of expertise, the joint creation of knowledge, the resource-based view, brokering activities, HRM (Human Resources Management) processes and the dynamic of scientific disciplines. The objects under investigation are very diverse; they include project teams, luxury hotels, urban projects, hospitals, clusters, the aeronautics industry and agricultural systems.

These studies draw on approaches that have become established over time. There is a history behind the succession of approaches in the field of knowledge management (Snowden, 2002),so it may be useful to put these various pieces of research into context. The central question of this special issue is that of boundaries: between projects, between organisations, between types of knowledge, between scientific disciplines and, of course, between actors. This examination of boundaries leads to a state of the art review that begins with the question of knowledge transfer. Van Wijk \& al. (2008) consider the antecedents of the transfer considering three major topics: knowledge, organizational and network characteristics. We take adifferent approachusing ahistorical approach to theconcepts. Following Tsoukas (1996, 2009), we propose to criticize the dominant approach of the transfer. In addition, we want to show and comment the change from the concept of knowledge transfer to the concept of boundary. In a constructivist way (Le Moigne, 1994, Von Glasersfeld, 1995) and with Holford (2015) we propose the concept of boundary construction in order to underline the role of interactions 'actors-objects-actors'.

We start by noting the importance of the studies that laid the foundations of the knowledge dynamic within organisations. Thus the variety of economic contexts and modalities of transfer is evoked; social capital and networks constituted key reference points for the analysis of knowledge transfer. Gradually, it became clear that what had emerged from an investigation of these various modalities of transfer was the importance of the quality of the relations between actors. In this sense, knowledge management is akin to much of organisation and communication theory. Nevertheless, certain gaps were identified in the theory, since it did not seem so easy to carry out transfers. This led in turn to attempts to identify the boundaries that were causing difficulties and that had to be crossed.

This led, secondly, to an examination of the role of boundaries. What status couldboundaries have when knowledge was expanding enormously within communities, and in particular when communities were operating autonomously outside organisations? The same question arose when new actors appeared to establish methods of extracting knowledge and to assist the experts. Finally, we come face to face with knowledge management systems that have tended to redefine the forms that boundaries take.

\section{Knowledge and boundaries: knowledge transfer deadlocked}


The notion of transfer marked an important stage in early approaches to knowledge management. Nonaka's SECI (Socialization, Externalization, Combination, Internalization) model became very widely cited, on occasions excessively so.

Having identified the need for transfer, the studies went back to investigate the sources of knowledge transfer practices. Knowledge transfer is the process through which one network member is affected by the experience of another (Argote and Ingram, 2000).

The notion of transfer implies the existence of skilled actors and hence of divisions and boundaries between them, as well as a plan for carrying out the transfer in a number of stages. Having investigated the question of transfer, researchers began to turn their attention towards that of boundaries. Our initial aim here is to evaluate the insights provided by these studies, particularly by highlighting the difficulties that have been identified with regard to both the transfer process and boundaries.

\subsection{Knowledge transfer as a strategic challenge \\ 1.1.1. From challenge to implementation}

Transferring knowledge has become a strategic action that is a particularly important factor in determining the success of alliances between a number of firms (Doz, 1996, Simonin, 1999), ensuring that experience is shared between the subsidiaries of a multinational company (Hedlund, 1994) or facilitating the diffusion of technologies between several departments (Allen, 1979, Amesse, 2001).

The multinational Bosch organises its knowledge transfer around a powerful socio-technical system. It consists of an intranet (the third largest in the world) that links 160,000 employees across several tens of subsidiaries and a set of very strong incentives for technicians to move around the company for longer or shorter periods of time in order to facilitate the transfer of skills, knowledge and know-how (Bender and Fish, 2000).Experiments of this kind have been described frequently. A successful transfer of knowledge cannot be likened to the mere transmission of knowledge. An efficient information system has to be combined with a system of varied and frequent contacts between employees (Davenport and Prusak, 1998).

Knowledge transfer has been studied in detail in strategic transition situations, e.g. in the case of joint ventures and alliances. With such strategies, the ability to re-evaluate situations and to learn from the experience of bringing two entities together is presented as an important factor in their success(Inkpen, 1996; Doz, 1996; Mowery, 1998).

These analyses were extended by investigating other transition situations.Bresman (1999), for example, analyses knowledge transfer in international acquisitions. The firm is analysed as a set of professional communities with the aim of identifying which arrangements might best facilitate the transfer of knowledge between them. The following methods are identified: faceto-face communication, visits and meetings between partners in the alliance and codification (patents and so-called 'grey literature' ${ }^{1}$ ). It is noted that time tends to improve knowledge transfer.

Everything depends, of course, on how mature the alliance is. Over time, organisations merge and it becomes increasingly difficult to detect the flows of knowledge between two previously

\footnotetext{
${ }^{1}$ 'That which is produced on all levels of government, academics, business and industry in print and electronic formats, but which is not controlled by commercial publishers.' (Definition agreed at the Fourth International Conference on Grey Literature: New Frontiers in Grey Literature. GreyNet, Grey Literature Network Service, Washington DC, USA, 4-5 October 1999.
} 
separate entities. At the beginning of an alliance, the flow is unidirectional and mainly concerns codified knowledge. Subsequently, the process tends to go into reverse.

One fundamental point that emerged from these approaches was that the contexts in which communication takes place were decisive. These studies located the question of transfer within the organisational dynamic. The social and organisational dimensions of knowledge were established as decisive factors and efforts were made to identify the best ways of facilitating the integration of knowledge within an organisation. To that end, two main lines of inquiry were opened up. The first focused on organisational design, with the main object of investigation being an organisation's capacities for integration, such as modularity (Sanchez, 2000) or virtuality (Davidow \& Malone, 1992), the second on networks \& social capital (Gulati, 2000, Inkpen \& Tsang, 2005, Nahapiet \& Ghoshal, 1998).

Analyses of networks and social capital focused on individuals and their capacity to connect with each other. Through their various relations, individuals build up social capital, while networks are the representation of that capital. Social capital 'represents the ability of actors to secure benefits by virtue of membership in social networks or other social structures' (Portes, 1998).

These studies were structured by two central questions at the individual and collective level. How do the various dimensions of social capital influence an organisation's capacity to acquire new knowledge? And what are the conditions that facilitate knowledge transfer?

The areas of inquiry were very varied. Strategic networks include intra-corporate business units, strategic alliances, franchises, $R \& D$ consortia, buyer-supplier relationships, business groups, trade associations and government-sponsored technology programmes. In each of these situations, relational networks provide access to knowledge. These networks were analysed on the basis of three main dimensions - structural, cognitive and relational.

The conditions that facilitate knowledge transfer are contingent upon the various network configurations. Knowledge transfers can be carried out more easily within a firm's network if they take place between employees acting autonomously (Orlikowski, 2002), if authority is decentralised and if labour turnover is low (structural network ties dimension). As far as the cognitive dimension is concerned, the organisation's collective vision and objectives have to be shared; if the firm is an international one, the various cultures have to accommodate one another. Finally, as far as the relational dimension is concerned, the risks of misunderstanding have to be contained by developing a clear incentive system. However, other network structures, and hence other types of social capital, require different conditions (Inkpen \& Tsang, 2005: 155).

Thus knowledge transfer became a matter of the structure of the social capital in the network in question and hence also a matter of culture. The quality of the ties between members of the same network or between different networks came to be regarded as a fertile source of research. In particular, individual social capital was defined as the most relevant level at which to investigate the transfer of tacit knowledge.

Network structure continues to engender numerous studies of knowledge transfer, with a particular focus on the question of intercultural management. Trust and open-mindedness are two dimensions that are much discussed from the point of view of knowledge transfer within multinationals (Boh, Nguyen \&Xu, 2013).

\subsubsection{A multi-level approach to knowledge transfer}

This initial characterisation of the transfer process was to be extended by taking into account the distinction between codified and tacit knowledge. Zander (2002) takes the view that tacit 
knowledge is more difficult to transfer than explicit knowledge. It was often to be concluded that:"high care relationships favour both the transfer and creation of knowledge" (Zárraga \& Bonache, 2005).The quality of relations was to be the object of very detailed studies.

Von Krogh deploys the notion of 'care', defined as 'serious attention' (heed) and as a 'feeling of concern and interest' in the other (Von Krogh, 1998).He studies relational contexts in terms of behaviours and effects on the knowledge dynamic. These contexts are structured by management processes (employee evaluation systems, information systems) and by a set of attitudes and behaviours. The resultant quality of relations determines the possibilities for sharing and creating knowledge (Simoni, 2012).

Five behaviours are used to describe the level of care in organisations: mutual trust, active empathy, access to help, leniency in judgement and courage. The presence of these behaviours is characteristic of high-care relationships while their absence denotes low-care relationships. This marks a progression in the conceptualisation of knowledge transfer: knowledge is closely linked to individuals' actions and transfer cannot be considered without a detailed investigation of the system of relations. A general approach to knowledge sharing has to incorporate the human resources devoted to providing the care bestowed upon relations. Thus, for example, managers have an important role to play as 'knowledge activists' (Von Krogh, 2003).

The introduction of relational contexts brings us close to cultural and communication studies. In fact, a very different typology of knowledge management had already been developed by Hansen and al. (1999). Hansen and al.'s model establishes a link between knowledge management strategies, business models and organisational cultures. There is a degree of consistency between a knowledge management strategy and an organisation's value network. Two very distinct strategies are defined: codification and personalisation.

Codification is appropriate for repetitive business models. Operations are standardised and monitoring efficiency is the key to ensuring the productivity of both manufacturing and commercial units. In this case, knowledge gains from being formalised and stored in large data bases. The knowledge management strategy is based on an approach that goes 'from people to documents' (Hansen \& al., 1999: 108). The personalisation strategy, on the other hand, is geared more towards creativity. Based on high levels of individual expertise, it can be characterised by the specific care bestowed upon the system of inter-employee relations. The tacit dimension of knowledge is greater and the knowledge management strategy develops 'from person to person' (Hansen \& al., 1999: 107). Knowledge management might, for example, take the form of small-group training sessions, tutorials and localised research.

Thus knowledge transfer took its place among the more general problems of management.Nevertheless, this did not put an end to the analysis of knowledge transfer. Knowledge is usually regarded as something (a resource, an object, a potential) that has to be shared. However, the actual detail of the transfer process is never explained. Thus at the same time there emerged a completely different analysis, based on the notion of boundary. Since knowledge transfer was now a question of culture, researchers started to focus attention on the personal barriers to transfer: individuals have no desire spontaneously to share their good ideas, they do not wish to use those of others and they regard themselves as more expert than their colleagues.

\subsection{From transfer to the construction of the boundary as a difficulty 1.2.1. Boundaries that are difficult to cross}


Despite considerable progress in defining relational contexts, the reality of knowledge transfer was called into question by a number of studies concerned with boundaries. The difficulty of making transfers is highlighted by the fact that knowledge is contextualised (Szulanski, 1996). This difficulty brings us back to the integration and differentiation model developed by Lawrence \& Lorsch (1967), which was described by Carlile (2002) as a syntactic approach to boundaries.

Three types of difficulty are often identified as affecting the transfer process. Firstly, it may take considerable time and expense to identify the relevant knowledge within an organisation. Secondly, it may prove difficult to transfer knowledge from one unit to another. Finally, knowledge transfer may be hampered if the units in question are too far apart culturally(Becker, 2001, Lahiri, 2010).

This questioning of the reality of the transfer process was intensified by Tsoukas' analysis(Tsouka 1996, 2009) of the processes of creating and expanding knowledge proposed by Nonaka \& Takeuchi (1995), who formalised the much-cited SECImodel. This model constitutes an attempt to systematise the development of knowledge in terms of the social interaction between tacit and explicit knowledge. Tsoukas denies that it is in any way possible to separate the tacit and explicit dimensions of knowledge: they are as intertwined with each other as if they were plaited together. "Tacit knowledge is not explicit knowledge " internalized ", as Nonaka \& Takeuchi (1995: 69) claim, noris it something which a firm may "lose" during a period of crisis, as Spender (1996:73) implies. Tacit knowledge is the necessary component of all knowledge; it is not made up of discrete beans which may be ground, lost, or reconstituted ... to split tacit from explicit knowledge is to miss the point-the two are inseparably related" (Tsoukas, 2009:99).If one goes along with Tsoukas, and we suggest to do it, tacit knowledge, which constitutes the major challenge in the transfer process, is simply not transferable! It can neither be captured nor translated into explicit knowledge. Tsoukas shows us that the question is in fact poorly formulated, since tacit knowledge manifests itself in what individuals achieve.

The remorselessness of this questioning helped to push the limits of the knowledge transfer question even further back. On the one hand, the studies that followed examined the cognitive dimensions of learning in greater detail. On the other hand, the conceptual framework used to analyse boundaries was extended. The invisible boundaries were analysed and identified (Hernes, 2004); they include mental boundaries (ideas and concepts linked to technologies), physical boundaries (rules of action in projects) and social boundaries (representation of practices and professions linked to identity). While these invisible boundaries can be considered as distinguishing attributes of knowledge, they also enable us to explore the relationship system between this knowledge and the structures in which it occurs.

\subsubsection{Boundary objects}

Since the question was and remains poorly formulated, researchers started to explore one of the activities that creates a great deal of knowledge, namely design activities. Boundary object analysis has proved particularly fruitful in this regard.

It was the article by Star \& Griesemer (1989) that paved the way for this type of boundary analysis. Knowledge is in fact as firmly located in the problems that arise as in individuals' practices. Objects constitute a punctuation, a boundary in the interactions that take place in the course of a design process. They are a manifestation of the boundary between two worlds. More specifically, "Boundary objects are objects which are both plastic enough to adapt to local needs and constraints of the several parties employing them, yet robust enough to maintain a common identity across sites. They are weakly structured in common use, and become strongly structured in individual-site use. They may be abstract or concrete. They 
have different meanings in different social worlds but their structure is common enough to more than one world to make them recognizable means of translation. The creation and management of boundary objects is key in developing and maintaining coherence across intersecting social worlds" (Star \& Griesemer, 1989: 393).

Carlile (2002) takes this approach a stage further by describing 'knowledge in practice' as 'localized, embedded and invested within a function'. He is concerned with the difficulties engineers and other specialists experience when working across functions. Rather than focusing on knowledge flows, he examines the objects that come into play in these attempts at mutual comprehension.

In design work, individuals work with objects (figures, technical notes, tools and machines) and results (sales contract, prototypes, order forms). Objects are transitory and always active; they are also ideal, in the sense that they are defined in terms of their relationship to the worlds in which they are deployed and for which they work (ends, purposes). Thus objects are vectors for representations, since they are shaped by an intention or objective originating in a social-technological-economic world linked in one way or another with that in which that objective is to be realised. For example, a drawing represents the dependencies between different designers and its consequences in terms of work progression.

Carlile identified four types of boundary objects: repositories, standardized forms and methods, objects or models and maps of boundaries. He also identified three principal characteristics that may facilitate knowledge transfer (Carlile, 2002:451-452):

- 'a boundary object establishes a shared syntax or language for individuals to represent their knowledge' (syntax),

- 'an effective boundary object ... provides a concrete means for individuals to specify and learn about their differences and dependencies across a given boundary' (semantic),

- 'an effective boundary object facilitates a process where individuals can jointly transform their knowledge' (pragmatic).

Carlile's contribution was crucial. On the one hand, he revived links with complex system modelling (Bertalanffy, 1968, Le Moigne, 1994) to point out that knowledge is a multidimensional system (Ermine, 1996). On the other hand, he started to examine the knowledge transfer process at what, in our view, is a more realistic level: 'this research demonstrates at a deeper level why communication across functional boundaries is hard, given the problematic nature of knowledge in practice' (Carlile, 2002:453).Ultimately, with this type of research, knowledge gains from being studied exhaustively as a process (knowing) rather than in terms of results or outcomes (knowledge).

Holford(2015)continuesthis approachby drawing onthe epistemologyof the activity (Suchman, 1987, 2006) and interrelated processes of enactment (Weick, 1995). The author underlines that a given object may take on simultaneous roles. The same view is assumed by David (2001) in the case of management tools. The author points out four roles for management tools and models: a traditional role of conformation, but also other roles: investigating organisational functioning, accompanying change and exploring new paths.

In this way, we follow Holford (2015) when he points: "super-positioned onto this is the concept of socially constructed world via interrelated processes of enactment (Weick, 1995) involving a complex environment of relational acts and responses. As such, we are now dealing with a two-way shaping process occurring between artefacts and perceiving/acting subjects". This conception of continuous two-way shaping process leads us to the question of knowing.

\subsection{Beyond transfer?}


We have outlined the studies that examine ways of facilitating knowledge transfer. One of the ways in which this research manifests itself is in analysis of the role of boundaries. However, knowledge cannot be manipulated, knowledge is subjective representation, knowledge is limited and represents a limit. Other approaches deserve to be incorporated into the analysis in order to go beyond, firstly, this concept of transfer and, secondly, the notion of boundary.

\subsubsection{From 'knowledge' to 'knowing': what are the implications?}

David Snowden (2002)provides an historical analysis of the formation of the concepts used in knowledge management. He emphasises various modes of structuring applied to the market in management concepts. He shows, for example, how Nonaka's SECI model persists in management models whereas its Cartesian reference points were to be sidelined a few years later by the approach based on the Japanese word Ba developed by the same author (Nonaka and Konno, 1998). Ba denotes a 'shared space for emerging relationships'.A whole set of management needs have accumulated around the notion of 'knowledge management' but without the real meaning of that perspective necessarily being understood. In fact, knowledge management is an oxymoron. Snowden strongly criticises the idea that voluntary processes are capable of identifying knowledge and transferring it. He puts forward a contextual and relational concept of knowledge that amounts to an acceptance of the paradox of knowledge, which is both an object and a flow.Holford (2015) says the same thing when he defines knowledge creation both as an end result and an ongoing emergent activity.

Knowledge does not exist in isolation; it requires experience of the subject (learning), of the situations and of the mediums (a language with its syntax and semantics). Language plays an important part, as in the subtle distinction between 'knowledge' and 'knowing'. Analyses of the transfer process had focused on the notion of 'knowledge'. The notion of 'knowing' takes us into a completely different world. "We use the term "knowing" to refer to the epistemological dimension of action itself. By "Knowing" we do not mean something that is used in action or something necessary to action, but rather something that is a part of action, both individual and group action" (Cook \& Brown, 1999: 387). This in turn takes us back to a theory of learning, from which several lessons can be drawn which will be summarised below.

One of the origins of 'knowing' as an activity is to be found in cultural anthropology and ethnomethodology. One of the first sources is to be found in the role of the 'psychological instruments' identified by Vygotski (1934). This is the 'language/thought' system: it is through their interactions that individuals in part construct their cognitive skills. For Vygotski's successors (Cicourel, Garfinkel, Goffman \& Schütz), the social world is interpreted in accordance with common sense categories and constructions, which are the resources that enable individuals to understand each other. ForBlumer (1966), meanings develop in the course of social interactions and are put to the test through a process of interpretation undertaken by individuals as they relate to things. Context is not an objective given but is continually being redefined in the course of interactions (Bateson, 1977). For Sperber \& Wilson (1989), context is a psychological construct. Rather, it develops in the course of exchanges; it is a subset of the listener's hypotheses about the world. Context enables interlocutors to understand each other. Misunderstandings arise out of the gaps between the contexts constructed by each subject. Weick $(1969,1986,1993)$ was to be one of the main heirs to these approaches. He was to hypothesise that the processes of attributing meaning lead to the formation of schemas that guide subsequent actions. Context which, as already noted, is constructed, plays a decisive role in thought processes: individuals act on the basis of their conception of it (enactment process). Reality is transformed to a certain extent under the impact of individual actions. Individuals then render that reality intelligible by drawing on the 'causal maps' they have developed through experience. In this way, a situation 
may become equivocal, i.e. it can be interpreted in several different ways without, for all that, becoming ambiguous or confused. This 'new' reality becomes significant for the individual concerned and is stored in the form of a causal map (retention process).

In sum, knowledge transfer is undoubtedly not the most relevant question. It is preferable to consider the processes of interaction and knowledge creation.Because the only transfer that takes place is that of information.

\subsubsection{An heuristic for creating knowledge through interactions (conversational sequencing)}

We turn now to another set of research questions, pertaining this time to the interactive processes that lead to knowledge creation. Brassac $(1994,2008)$ developed a methodology designed to facilitate the transmission of experience by using an approach based on the social psychology of cognitive processes. The commonest management situations are those involving the departure of a technician or engineer.

Knowledge acquisition is a process for which at least two actors ((L)earner and (K)nower) are both responsible. This process unfolds within a set of social interactions made up of discursive exchanges and gestural productions and through the manipulation of machinery. Under such circumstances, there is no knowledge transfer in the strict sense of the term. For the actors, the aim is to maintain these interactions. What emerges in fact is a series of jointly constructed meanings that are intended to be used and appropriated by $\mathrm{L}$ after the acquisition. In order to facilitate this appropriation, Brassac develops a methodology whereby as much data as possible is incorporated into the context of interaction. Simply making a record of the interaction is not sufficient. K's statements and L's understanding of those statements should not be disconnected from each other; K's expression of his expertise should not be isolated from the locus of its implementation; the two actors $\mathrm{K}$ and $\mathrm{L}$ should not be prevented from representing the various elements of the work graphically.

Thus $\mathrm{K}$ and $\mathrm{L}$ are given an opportunity to have a direct relationship, not only with knowledge and expertise and the attendant uncertainties and gaps but also with the limitations of dependency on documentation. The possibility is preserved of asking questions, pointing to inconsistencies, revealing conflicts and putting forward new points of view. Thus the prospects for sharing - more so than for transfer - are linked to the fact that the knowledge is distributed between $\mathrm{K}$ and the artefacts (documents, machinery, etc.). A good strategy, therefore, is one that encourages constant toing and froing between the various modes of knowledge 'gathering' (diversity, redundancy). In this way, gaps between performative utterances and lived experiences can be discovered and performance-enhancing recommendations and reformulations made.

How does this knowledge-creating heuristic differ from practices intended to improve the relational contexts in which knowledge transfer takes place?

As they investigated in greater detail the practices associated with knowing, researchers were concerning themselves with the detail of the cognitive process as such rather than just the organisational context. Consequently, the transfer process lost some of its strength and boundaries emerged as constructed by the actors, since perceptions shape intentions, which in turn serve to guide actions. From a methodological point of view, it had to be realised that there were still too many divisions between the various approaches concerned with the same object of investigation. The question of how to manage the mobilisation of knowledge, analysis of the cognitive processes involved in the construction of meaning and, finally, approaches to knowledge engineering were still too far removed from each other. In the following section, some simple ideas for reconciling these various approaches will be examined. 


\section{Knowing and boundary construction}

We have relativised the pertinence of knowledge transfer and called for a reconceptualisation of the notion of boundary. Our purpose is to show how boundaries are constructed and how they can be crossed. Boundaries are constructed by communities that operate independently of hierarchies (2.1); they are relativised by scientific and technological change through knowledge modelling (2.2.) and are transcended by mechanisms developed by organisations that make it possible to imagine a completely different viewpoint (2.3).

\subsection{Communities and knowing}

The concepts of community of practice and epistemic community (Haas, 1992, Cowan, 2000) introduced the question of power into the analysis of knowledge transfer and boundaries. Communities became the new object of investigation within organisations. 'We suggest that organizations are social communities in which individual and social expertise is transformed into economically useful products and services by the application of a set of higher-order organizing principles. Firms exist because they provide a social community of voluntaristic actions structured by organizing principles that are not reducible to individuals' (Kogut \& Zander, 1992: 384).

\subsubsection{A necessarily collective knowing}

Since the first studies of communities of technicians carried out by Orr (1990), a rich and diverse literature on the social construction of learning by employees has come into being. Drawing on North American sociology, further analyses of learning were to nullify knowledge transfer and extraction as research questions. Practice-based learning (Brown \& Duguid, 1991) is an autonomous act undertaken by individuals within a particular activity context. This context is structured by the collective action of communities of practice (CoPs), which solve practical problems on a daily basis by developing largely autonomous learning and knowledge sharing processes. Knowledge sharing is socialised and the new knowledge is created through interactions between individuals even when they are supposed to be working alone. As a result of the collective action undertaken by these communities, the social and cognitive dimensions are closely linked. This intertwining is not perceptible outside the community: one has to be part of it in order to share one's knowledge. Learning is a social construction (Lave, 1988) that obeys rules that take different forms in each community.

If learning is a construction, it is also a social practice in which meanings relating to the action are negotiated (Wenger, 1998). This practice is articulated around three dimensions:

- 'Mutual engagement': the individual members of the community are engaged in actions whose meaning they negotiate with each other. This engagement is based on the complementarity of their knowledge, individuals' capacity to connect this knowledge and relationships based on mutual assistance;

- 'Joint enterprise': the community's fairly immediate objectives are (re)defined in the course of a collective negotiating process;

- 'Shared repertoire': the sharing of a common practice makes it possible to create resources (procedures, routines, concepts and symbols) on which community members can draw when negotiating meanings. Thanks to these resources, the shared repertoire not only provides reference points but also includes a certain degree of ambiguity, which is essential to the negotiations.

Under these circumstances, the boundaries between departments and between types of knowledge are constructed by the communities' autonomous actions. As far as organisations are concerned, there is a risk that they will be diverted from their objectives or that the community will be prevented from making progress in their productive projects (McDermott 
$\&$ Archibald, 2010). Consequently, these communities require some form of governance, with some organisations going so far as to create new communities (Bootz\& all.,2013) reports numerous instances of community creation and governance by organisations (British Petroleum, EDF, European Council, GDF-Suez, IBM, Schlumberger). The aim is to direct the work of these communities and to equip them with the necessary resources. Coordinators can facilitate the circulation of information and diffuse good practices, while sponsors can act as spokespersons and advocates for their communities.

In general terms, the fact that communities of practice are autonomous must be perceived as a managerial innovation and not as an organisational risk (Créplet \& Dupoët, 2009).This innovation involves the assumption of a diversity of roles within management. Hierarchies can create a favourable context for the development of communities by avoiding making contradictory stipulations with regard to rules and norms. Other managers should be in charge of knowledge diversity and protecting communities' autonomy.

\subsubsection{Negotiating boundaries}

The relations between communities and management hierarchies constitute a delicate boundary construction. This is all the more the case when an organisation needs the expertise of an external community (Cohendet \& Simon, 2007). In the video games industry, most companies entrust core knowledge production to external communities. These communities comprise individuals who operate outside of any wage relationship or even commercial contract. However, their members take part in companies' creative projects and gradually contribute to the formation of a 'creative slack' that is the core of the company's innovative potential. This 'creative slack' is distributed in part in the company's formalised knowledge base and in part in the knowledge communities' cognitive functioning.

From a dynamic point of view, a community is based on self-developed norms that actually constitute action guides. Non-compliance with these norms causes the viability of the community's evolution to be called into question (Munier, 2013).On the face of it, the hierarchy and the communities are governed by conflicting sets of rules. Communities may be exposed to pressures from their environment, for example from a management hierarchy with which it is associated. However, the community is creative, through the construction of its own norms and, more generally, the interactions between its members. The companycommunity relationship can be understood in terms of pressure exerted by the former on the latter (Munier, 2013). A community is viable to the extent that it respects social norms defined by its members. Its actions evolve within a repertoire of norms. Consequently, the community can match its actions to these pressures if, and only if, the norms corresponding to its actions belong to the repertoire of possible norms. Thus the company, as a regulatory body, has constantly to find a balance between two constraints: respecting the norms by which the community operates, on the one hand, and, on the other, the possibility of tapping into and managing that community.

In this case, the boundary is constructed through a permanent process of negotiation between the different types of organisation.

\subsection{Knowledge modelling}

The purpose of knowledge modelling is to facilitate transmission between different partners. It is concerned with the existence of knowledge as such. Use of the various modelling methods introduces new actors into the transfer process and alters the representation of boundaries.

\subsubsection{From systemic design to knowledge transmission}


MASK (Modelling, Analysis and Structuring Knowledge) is one of the most complete knowledge modelling methods. It is based on two fundamental principles: all organisations have their own organisational knowledge, the complexity of which requires specific modelling (Ermine, 2007).

The first principle is that a firm possesses a body of 'organisational knowledge' that is preserved over time in the form of information outputs (documents, databases, software, etc.) or through individual and/or collective exchanges and transfers. It accumulates within the firm over the course of its history and constitutes what is known as its 'knowledge capital'.

The second principle is that organisational knowledge is a complex system. Consequently, it can be rendered intelligible and manageable only through a pluralist mode of representation that uses systemic modelling. Based on these two principles, the MASK method comprises four phases.

- Strategic analysis of an organisation's knowledge capital, with the aim of identifying the knowledge domains that are 'critical' to the organisation. What knowledge is really threatened? Is it really strategic for the organisation? Who has possession of this knowledge? What are the types of operational action to be considered? An audit of the knowledge capital and a plan for preserving and transferring the knowledge are drawn up.

- Extraction of the knowledge capital. This phase concerns all critical and strategic knowledge domains, with a high tacit component, in which the tacit element is held essentially by identified experts. The extraction phase involves gathering knowledge from the experts in order to formalise their unwritten knowledge so that it can be shared with other people in the same area of expertise or engaged in very similar activities.

- Transfer of the knowledge capital. Extraction makes it possible to gather and structure the sensitive content of a knowledge domain and thus to assembly a body of domain-specific knowledge. The task then is to take this body of knowledge and transfer it to a community that is to use it for its operational practices. It is at this point that the real problems of transfer become apparent. How are the mechanisms for transferring the body of knowledge to be designed, in view of the objective, the target and the environment concerned?

- Innovation based on the knowledge transferred. The process continues with the organisation's ability to develop its knowledge capital from a strategic point of view. All the resources created in the previous phases have to be used as innovation levers through the creation of knowledge.

\subsubsection{New actors to share the knowledge}

Like others, this method uses the term 'transfer', but the means used show that we are dealing with a more complex construction.

In its four phases, MASK uses tools that require particular expertise: cognitive maps (strategic maps, maps of the knowledge domains), analytical frameworks ('critical knowledge factors'), cognitive modelling tools (tasks, activities, concepts, lineages, phenomena, etc.) and transfer and evolution models. This modelling activity is undertaken by specialist consultancy companies or by 'knowledge managers' employed by the firm.

This type of method also requires particular expertise to represent knowledge. This involves systemic modelling, which is based on two important hypotheses (Ermine, 1996: 20-22). The semiotic hypothesis (or semiotic triangle) converts the knowledge into a system of signs. A sign (any perceptible phenomenon) can be presented in three dimensions: its syntax (structure, operating rules), its semantics (meaning, signifier) and its pragmatic dimension. The second hypothesis (or systemic triangle) turns the knowledge into a dynamic system that can be 
represented in three dimensions: its existence (be), its functionality (do) and its future (evolve). On the basis of these hypotheses, very precise knowledge maps can be drawn up within an organisation, which may make it easier to share the experience of certain experts. However, this mapping requires an ability to stand back from current activities. It also requires the involvement of experts and of employees who are not experts in their field. In fact, the task of representing the knowledge and making it available is a collective activity, the aim of which is to have a set of knowledge explained to one individual by another individual.This activity takes up a significant amount of time. It requires experts to define what they know in a new way. They are impelled to discover what they know and what they do not know, as well as what they might know.

The practice of providing support is thus extended. It is clearly differentiated from the activities of the 'coordinators' who operate around communities of practice (Bootz and all., 2013) and from those of 'knowledge activists' (Von Krogh \&al., 1997, 2000). The aim is to make use of individuals' experience by expressing it in a syntax that is far removed from their normal practice. Representing experience in the form of a knowledge system with its concepts and lineages necessarily constitutes an original knowledge creation exercise for each of the protagonists.

What we have here is an illustration of boundary work. The expert's knowledge is extracted, represented and made available in a particular form. In this way, the boundary between the individual who knows in an expert way and the individual who is preparing to know is constructed. We cannot speak about knowledge transfer. Rather we can tell about coconstruction of information who represents knowledge.This knowledge is available to the actors who want to shape another knowledge in a processual continuum (Chia \& Mackay, 2007, Holford, 2015).

\subsection{Boundary work}

These two approaches to knowledge sharing (communities and modelling) show that a structure is always present to open the way to learning. This also shows us that, although there are certainly boundaries between occupations, departments and disciplines, they are in every case social and cognitive constructions. Such constructions can be called 'boundary work'. Several studies provide illustrations of what this implies in terms of organisational dynamic.

\subsubsection{Cognitive devices}

A number of studies are positioned between organisational theory and cognitive psychology. They are concerned with the devicesthat organisations put in place in order to encourage knowledge creation and sharing. Access to its members' knowledge is mediated for an organisation through three dimensions: cognitive structures (schemas, beliefs, scenarios), cognitive processes (the particular way in which knowledge is selected, organised and transformed) and cognitive styles, which describe the individual, collective and organisational differences in information processing (Schneider \& Angelmar, 1993). In an attempt to control transaction costs and the risks of cognitive estrangement, several factors are often presented as likely to strengthen the social and cognitive ties between members. They include training, making reality more intelligible and orderly, organisational learning through the diffusion of ideas and organisational memory (Jelinek \& Litterer, 1994). These unifying processes make up what is called a device.

The concept of the dispositif(usually rendered in English as 'device') was developed in the mid-1970s by the French philosopher Michel Foucault. He defines the dispositif as the system of relations that can be established between heterogeneous elements that gradually form an 
ensemble consisting of discourses, institutions, laws, physical spaces, administrative measures, scientific statements and philosophical and moral propositions (Foucault, 1976).

For organisations and in the cognitive domain, adevice is defined as an organised and targeted set of objects that are linked to each other and distributed in space for the purpose of producing goods or knowledge(Poitou, 1995, 1997).The intellectual objects have the capacity to trigger certain intellectual, practical and technical processes inherent in the artificial objects (automatic devices and machines). These processes use the resources of a mental toolkit. This is to say that individuals work with a set of technical tools that are all based on a mental toolkit (all the instruments the mind uses to function).This organisation of the individual mind is dependent on the tools available to the organisation in general. For example, an organisation's memory is determined by the quality of the various intellectual objects and mental tools assembled within it. Thus cognitive and organisational activities are inseparable.

These devices are never stable but are constantly being reconstituted in time and in space. An individual at work does not need to use all the available knowledge. This is what makes possible the variety and discontinuity of both human activities and the different forms of cooperation. In fact, the knowledge is situated in the work environment and distributed among all the constituent technical elements and the operators. This distribution is not immutable but is constantly being renewed depending on the needs of the various operational phases and the cooperative interactions between the agents. Organising and carrying out these processes of redistribution constitutes a knowledge management activity (Poitou, 1995,1997).

What forms do these devices take and what learning processes can be carried out? These devices are put in place in order to meet needs for intensive innovation. A typology and some specific examples are provided in the field of research and development (Charue-Duboc, 2006, 2007). These devices are developed in order to encourage learning between projects, with external entities or by exploration.

Inter-projectdevicesseek to establish continuities between experiences that may be far removed from each other. This can be done by identifying links between products and then between technological competences(LeMasson, Weil \& Hatchuel 2006). Another possible method is to draw up standardised protocols for research activities and to appoint experts to oversee the learning processes within a department (Charue-Duboc, 2007).

The devices established with external entities stand in the tradition of so-called 'boundary spanners' (Allen, 1979) and 'absorptive capacity' (Cohen and Levinthal, 1990). Recent developments (Charue-Duboc) have identified two models. In the first, the disciplinary divisions within the academic world are reproduced within firms in order to facilitate external relations. In the second, a structure that cuts across the academic disciplines is put in place for each problem. Different types of expertise are brought together within a department in order to provide competences in areas common to a number of different projects.

Those devices that encourage learning by exploration are given over to non-targeted activities. For example, a firm might allocate each researcher a period of free time not given over to producing a pre-defined outcome while at the same time requesting an annual report on this activity. Another possibility is to bring together networks of experts to collaborate over several years in order to generate knowledge in response to questions that cut across different projects. This type of device is frequently put in place by electronics companies (Paraponaris, 2007). 


\subsubsection{Towardsboundary construction}

Having reached the end of this state-of-the-art review, we note that research is now being directed towards a new phase. The focus of attention is no longer on boundaries and the frequently difficult task of crossing them but rather on the hybridisation of knowledge, the collective creation of new conceptsand finally thecontinuous process of formationof boundaries betweensubject and object. As Snowden (2002) explained, knowledge management theories are constructed within a lineage of concepts that have been widely adopted one after the other and then supplanted by others.

The notions of transfer and boundary demonstrated their usefulness in the development of a new theory, namely the knowledge-based view. These concepts were then critiqued, with reference, firstly, to the contexts in which communication takes place and, secondly, to the cognitive dimensions of the activity. Finally, studies showed that the cognitive and organisational approaches can be linked and that they shed light on many knowledge sharing situations. Boundaries are no longer the object of attention, the focus having switched to the collective process of creating new concepts, in other words, the continuous process of building new boundaries.

Three series of studies illustrate this change of direction.

The first has its roots in the sociology of science (Shinn, 1997). An opposition has emerged in this field between studies indicating that the boundaries between scientific boundaries are extremely rigid and those highlighting 'the seamless web', i.e. s a strong trend towards convergence between disciplines(Bijke, 1997, Callon, 1986, Latour, 1979). The author shows that different scientific communities may be converging with each other but that this convergence it taking place by drawing on the resources made available by the division of labour between disciplines. More generally, high levels of knowledge hybridisation can be observed, not only between scientific disciplines but also between science and technology (instruments) and between companies and external entities.

The second has its origins in education sciences (Engeström, 1987, 2010). Here also, two concepts of learning are opposed to each other, namely knowledge acquisition theory and individual participation theory. It is possible to go beyond this opposition by adopting the concept of 'expansive learning': learners learn something that is not yet and "boundary crossing"entails stepping into unfamiliar domains. It is essentially a creative endeavour which requires new conceptual resources. In this sense, boundary crossing involves collective concept formation.'(Engeström, 2010).

The third is focused on boundary objects (Holford, 2015). This study uses a theory of the subject. Individual actors get an active role in knowing within different situations (Suchman, 1987) andemergence is essentially a dynamic state of becoming (Heidegger, 1962): the just emerged (as experiences) residing within the 'eye of the beholder' (or perceiving subjects) are interfacing one another.

With this theory of the subject, we can associate an epistemology of possession (knowledge) and an epistemology of action (knowing). The theory of Holford is a constructivist theory of boundary objects: objects are not pre-existent but emerge from cognitive constructions (Glasersfeld, 2002), enactments (Weick, 2009), agency (Barad, 2007) and situated actions (Suchman, 2006).Humans and objects not only interact, but intra-act, then we abandon the subject-object duality.

This process interact-intra-act is called boundary construction. It's an alternative to the current juxtaposition of approaches which encompasses the different roles of artefacts lying at the interface between two or more interacting individuals or groups. The boundary 
construction can be viewed as being both a process of construction and an outcome (Holford, 2015).

The boundary objects are continually constructed and reconstructed by the subjectactors.Holford argues with Orlikowski (2007) for an alternative approach of materiality and organizing, one that posits the constitutive entanglement of the social and the material in everyday life.Boundary constructions are in a constant flux of actual (and potential) coconstruction and reconstruction at the hands of intra-acting actors. Human-objects interactions are in a mutual shaping process.

These three fields of research are shot through with tensions between several theories. In each case, however, different approaches can be envisaged. The primary aim of these different approaches is not to reconcile warring brothers. What they offer, rather, is a reformulation of the cognitive dynamics that rigorously interrogate the established divisions.

Knowledge hybridization is possible but must be referred to resources made available by the division of labour between disciplines (Shinn, 1997). Expansive learning (Engeström, 2010) is close to boundary construction (Holford, 2015) in order to indicate the dialectical view between instituting and instituted society(Castoriadis, 1975, 1987). We are now perhaps at the point of transition between the interest in 'boundary spanners' and a new concern with 'boundary construction'.

\section{References}

Allen T.J., Lee D.M.S., \& Tushman M.L., (1979) "Technology transfer as a function of position in the spectrum from research trough development to technical services", Academy of Management Journal, 22, 4: 694-708.

Amesse F. \& Cohendet P.,(2001) "Technology Transfer revisited from the perspective of the knowledge-based economy", Research Policy, 30, 9: 1459-1478.

Argote L. \& Ingram P., (2000) "Knowledge transfer: A basis for competitive advantage in firms". Organizational Behavior and Human Decision Processes, 82: 150-169.

Barad, K. (2007)Meeting the Universe Halfway: Quantum Physics and the Entanglement of Matter and Meaning. Duke University Press. Durham, NC.

Bateson G.,(1977) Ecology of mind, Eds du Seuil, France, tome 1:13.

Bertalanffy, L von (1968) General system theory, foundation, development, applications, New York; G. Braziller.

Becker M.C., (2001) "Managing dispersed knowledge: organizational problems, managerial strategies and their effectiveness", Journal of Management Studies, 38, 7: 1037-1051.

Bender S., Fish A., (2000) "The transfer of knowledge and the retention of expertise: the continuing need for global assignments", Journal of Knowledge Management, 4, 2: 125-137.

Bijke, W. (1997) Of Bicycles, Bakelites and Bulbs. Toward a Theory of Sociotechnological Change. Cambridge, MA: MIT Press.

Blumer H., (1966) "Sociological implications of the though of George Herbert Mead", American Journal of Sociology, 71, 5: 535-548.

Boh W.F, Nguyen T.T, \& Xu Y., (2013) "Knowledge transfer across dissimilar cultures “. Journal of Knowledge Management, 17, 1: 29-46. 
Bootz J.P., Dupouët O., Kern F. \& Schenk E., (2013) "Governing communities of experts" in Hurger-Helmchen, T (Editor), The Economics of Creativity, Routledge, UK, 89-109.

Brassac C., (1994) "Speech acts and conversational sequencing", Pragmatics and Cognition, 2, 1: 191-205.

BrassacC., Fixmer P., MondadaL.\&Vinck D., (2008)“'Interweaving Objects,Gestures, and Talk in Context".Mind, Culture, and Activity, Taylor \&Francis (Routledge), 15, 2: 208-233.

Bresman H., Birkinshaw J., \&Nobel R., (1999) "Knowledge Transfer in International Acquisitions" Journal of International Business Studies, 30, 3: 439-462.

Brown J.S.\& Duguid P., (1991) "Organizational learning and communities-of-practice: Toward a unified view of working, learning and innovation". Organization Science, 2, 1: 4057.

Brown J.S.\& Duguid P., (2001) "Knowledge and Organization: A Social-Practice Perspective”, Organization Science, 12, 2: 198-213.

Callon, M. (1986) "Eléments pour une sociologie de la traduction: la domesticationdes coquilles Saint-Jacques et des marins-pêcheurs dans la baie de Saint-Brieuc',L'Année Sociologique, 36: 169-208.

Carlile P.R., (2002) "A Pragmatic View of Knowledge and Boundaries: Boundary Objects in New Product Development”, Organization Science, 13, 4: 442-455.

Castoriaids, C., $(1975,1987)$ The Imaginary Institution of Society. Polity Press, Cambridge, UK.First published as L 'institution imaginaire de la société, by Les Editions du Seuil.

Charue-Duboc F., (2006) "A Theoretical Framework for Understanding the Organization of the R\&D Function. An Empirical Illustration from the Chemical and Pharmaceutical Industry", International Journal of Innovation Management, 10, 4: 455-476.

Charue-Duboc F., (2007) "Dynamiques des connaissances et dynamique d'innovation", Réalités Industrielles, mai, 32-37.

Chia, R., \& MacKay, B. (2007)"Post-processual challenges for the emerging strategy-aspractice perspective: Discovering strategy in the logic of practice". Human Relations, 60, $217-242$.

Cohen W.M.\& Levinthal D., (1990) "Absorptive capacity: A new perspective on learning and innovation", Administrative Science Quarterly, 35, 1: 1-25.

Cohendet P.\& Simon L., (2007) "Playing Across the Playground: Paradoxes of Knowledge Creation in the Video Game Industry", Journal of Organizational Behavior, 28: 587-605.

Cook S.D.N. \& Brown J.S., (1999) Bridging Espistemologies: The Generative Dance Between Organizational Knowledge and Organizational Knowing, Organization Science, 10, 4: 381-400.

Cowan R., David P.A.\& Foray D., (2000) "The explicit economics of knowledge codification and tacitness", Industrial and Corporate Change, 9, 2: 212-253.

Créplet F., \& Dupouet O., (2009) «Communautés d'apprentissage et pratiques prospectives : de l'aide à la décision au management des connaissances » in Bootz J.P \& Kern F., Les communautés en pratique : leviers de changements pour l'entrepreneur et le manager, Editions Hermès - Lavoisier. 
Davenport T.H. \&Prusak L., (1998) Working Knowledge: How Organizations Manage What They Know, Harvard Business School Press, Boston, MA.

Davidow W.H \& Malone M.S., (1992) The virtual corporation. Structuring and revitalizing the corporation for the 21 st century. New York: Harper Business.

David, A. (2001). "Models implementation: A state of the art". European Journal of Operational Research, 134, 459-480.

Doz Y., (1996) "The evolution of cooperation in strategic alliances: Initial conditions or learning processes?” Strategic Management Journal, 17 (Special issue): 55-84.

Engeström Y., (1987) Learning by expanding: an activity-theoretical approach to developmental research. Helsinki: Orienta-Konsultit.

Engeström Y.\& Sannino A., (2010) "Studies of expansive learning: Foundations, findings and future challenges". Educational Research Review, 5 : 1-24.

Ermine J.L., (1996) Les systèmes de connaissances. Editions Hermès.

Ermine J.L., (2007) Management des connaissances en entreprise. Lavoisier. Paris, Hermès Science.

Foucault M., (1976) Histoire de la sexualité 1 : La volonté de savoir, Paris, Gallimard.

Gulati R., Nohria N. \& Zaheer A., (2000)“Strategic Networks”, Strategic Management Journal, 21: 203-215.

Haas P.M., (1992) "Banning Chlorofluorocarbons: Epistemic Community Efforts to Protect Stratospheric Ozone”, International Organization, 46, 1:187-244.

Hansen M.T., Nohria N.\& Tierney T., (1999) "What's your strategy for managing knowledge?"Harvard Business Review, March-April: 106-116.

Hedlund, G, (1994) "A model of knowledge management and the N- form corporation." Strategic Management Journal, 15 (special issue): 73-91.

Heidegger, M., (1962) Being and Time. Harper and Row, New York.

Hernes T. (2004) "Studying Composite boundaries: A Framework of analysis", Human Relations, 57: 9-29.

Holford, W. D. (2015)"Boundary constructions as knowledge flows within and between work groups". Knowledge Management Research \& Practice.Advance copy online, 13, 2.

Inkpen A.C.\& Tsang E.W.K., (2005) "Social Capital, Networks, and Knowledge Transfer", Academy of Management Review, 30, 1: 146-165.

Inkpen A.C., (1996) "Creating knowledge through collaboration". California Management Review, 39: 123-140.

Jelinek M. \&Litterer J.A., (1994), "Towards a cognitive theory of organizations", p. 3-41 in Stubbart C., Meindl J.R., \& Porac J.F. (dir) Advances in managerial cognition and organizational information processing (vol. 5). Greenwich, CT: JAI Press.

Kogut B. \& Zander U., (1992) "Knowledge of the Firm: Combinative Capabilities and the Replication of Technology", Organization Science, 3, 3:383-397.

Lahiri N., (2010) "Geographic distribution of R\&D activity: how does it affect innovation quality?” Academy of Management Journal, 53, 5: 1194-1209. 
Latour, B. and Woolgar, S., (1979) Laboratory Life: The Social Construction of Scientific Facts. London and Beverly Hills, CA: Sage Publications. (2nd edn 1986, Princeton, NJ: Princeton University Press.)

Lave J., (1988) Cognition in Practice. Cambridge: Cambridge University Press.

Lawrence P.R.\& Lorsch J.W., (1967) Organization and Environment. Differentiation and integration. Harvard University Press.

LeMasson P., Weil B. \& Hatchuel A., (2006) Les processus d'innovation: conception innovante et croissance des entreprises. Hermès : Paris.

Le Moigne J.L, (1994) La théorie du système général : théorie de la modélisation, Paris, PUF, (4 éd.).

McDermott R. \& Archibald D., (2010) "Harnessing your staff's informal network", Harvard Business Review, March, 1-7.

Mowery D.C., Oxley J.E. \& Silverman B.S., (1998) "Technological overlap and interfirm cooperation: Implications for the resource-based view of the firm", Research Policy, 27: 507523.

Munier F., (2013) "Creativity and uncertainty in the act of work: the contribution of the viability theory" in Hurger-Helmchen, T (Editor), The Economics of Creativity, Routledge, UK, 327-338.

Nahapiet J.\& Ghoshal S., (1998) "Social capital, intellectual capital, and the organizational advantage", Academy of Management Review, 23, 2: 242-266.

Nonaka I. \& Takeuchi H., (1995) The Knowledge-Creating Company: How Japanese Companies Create the Dynamics of Innovation, Oxford University Press Inc.

Nonaka I.\& Konno N., (1998) "The concept of "Ba: Building Foundation for Knowledge Creation." California Management Review, 40, 3: 40-54.

Orlikowski, W.J., (2002) "Knowing in practice: Enacting a collective capability in distributed organizing”. Organization Science, 10: 249-273.

Orlikowski, W. J. (2007)“Sociomaterial Practices: Exploring Technology at Work”. Organization Studies, 28, 1435-1448.

Paraponaris C., (2007) "Managing Knowledge Diversity in Distributed Organizational Structures" in O'Sullivan K.,Strategic Knowledge Management in Multinational Organizations.New York: Information Science Reference, August: 275-298.

Poitou J.P, (1995) "Documentation is Knowledge: An Anthropological Approach to Corporate Knowledge Management", in Barthès J.P. (Ed), Proceedings of the Third International Symposium on the Management of Industrial and Corporate Knowledge. Compiègne, France : 91-103.

Poitou J.P, (1997) «La gestion collective des connaissances et la mémoire individuelle », in J.M. Fouet (Ed.) : Connaissances et savoir-faire en entreprise. Intégration et capitalisation. Paris, Hermès : 157-178.

Portes A., (1998) "Social capital: Its origins and applications in modern sociology". Annual Review of Sociology, 24: 1-24. 
Sanchez R., (2000) "Modular architectures, knowledge assets and organizational learning: New management processes for product creation". International Journal of Technology Management, 19, 6: 610-629.

Schneider S.C.\& Angelmar R., (1993) « Cognition in organizational analysis: who's minding the store? », Organization Studies, 14, 3: 347-374.

Shinn T., (1997) "Crossing boundaries: the emergence of research-technology communities" in Henry E., Loet L. (eds.), Universities and the global knowledge economy: a triple helix of university-industry-government relations, London, Cassel Academic Press, pp. 85-96.

Simoni G., (2012) «Relancer la dynamique de connaissances dans des contextes relationnels dégradés ». Management \& Avenir, 7, 57: 14-36.

Simonin B.L., (1999) "Ambiguity and the process of knowledge transfer in strategic alliances », Strategic Management Journal, 20, 7: 595-623,

Snowden D., (2002) "Complex acts of knowing: paradox and descriptive self-awareness" Journal of Knowledge Management, 6, 2: 100-111.

SperberA. \& Wilson D (1989) La pertinence, communication et cognition, Paris : Minuit Edition.

Star S.L \& Griesemer J.R., (1989) "Institutional Ecology, 'Translations' and Boundary Objects: Amateurs and Professionals in Berkeley's Museum of Vertebrate Zoology, 1907-39". Social Studies of Science, 19, 4: 387-420.

Suchman, L., (1987)Plans and situated actions: the problem of human/machine communication. Cambridge:Cambridge University Press.

Suchman, L., (2006)Human-Machine Reconfigurations: Plans and Situated Actions (2nd edition). Cambridge ; New York: Cambridge University Press.

Szulanski G., (1996) «Exploring internal stickiness: Impediments to the transfer of best practice within the firm », Strategic Management Journal, 17, Special Issue: 27-43.

Tsoukas H.,(1996) "The firm as a distributed knowledge system", Strategic Management Journal, 17, Winter Special Issue: 11-25.

Tsoukas H., (2009) "The firm as a distributed knowledge system: A constructionist Approach" in Tsoukas, H, Complex knowledge. Studies in Organizational Epistemology. Oxford University Press: 94-116.

Van Wijk, R., Jansen, J. J. P., \& Lyles, M. A. (2008)“'Inter- and Intra-Organizational Knowledge Transfer: A Meta-Analytic Review and Assessment of its Antecedents and Consequences". Journal of Management Studies, 45(4): 830-853.

VonGlasersfeld, E., (2013). Radical Constructivism. New York: Routledge.

Von Krogh G., Nonaka I.\& Ichijo K., (1997) “Develop knowledge activists!”,European Management Journal, 15, 5: 475-483.

Von Krogh G.,(1998) “Care in Knowledge Creation”, California Management Review, 40, 3: 133-154.

Von Krogh G., Ichijo K.\& Nonaka I., (2000) Enabling Knowledge Creation. How to Unlock the Mystery of Tacit Knowledge and Release the Power of Innovation.Oxford University Press. 
Von Krogh G., (2003) «Knowledge Sharing and the Communal Resource », in EasterbySmith M. \& Lyles M.A., The Blackwell Handbook of Organizational Learning and Knowledge Management, Blackwell Publishing: 372-393.

Vygotski L.S., (1934, 1986) Thought and Language, Cambridge (Mass.), The MIT Press.

Weick K.E., (1969) The Social Psychology of Organizing ( $2^{\circ}$ ed), Reading Mass, Addison Wesley.

Weick K.E. \& Bougon M.G., (1986) "Organisations as cognitive maps: charting ways to success and failure", in H.P. Sims, J \& Gioia, D.A, The thinking organization: Dynamics of organizational social cognition, Jossey-Bass, San Francisco: 102-135.

Weick K.E.\& Roberts K.H., (1993) "Collective Mind in Organizations: Heedful Interrelating on Flight Desks”, Administrative Science Quaterly, 38, 3: 357-381.

Weick, K., (1995)Sensemaking in Organizations, Sage Publications, Thousand Oaks, CA.

Weick, K., (2009) Making Sense of the Organization (Volume 2): The Impermanent Organization. John Wiley and Sons Ltd, West Sussex UK.

Wenger E., (1998) Communities of practice: learning, meaning and identity. New York: Cambridge University Press.

Zander U., (2002) "The formation of International Innovation Networks in the Multinational Corporation: an Evolutionary Perspective", Industrial and Corporate Change, 11, 2: 327-353

Zárraga C.\& Bonache J., (2005) "The impact of team atmosphere on knowledge outcomes in selfmanaged teams". OrganizationStudies 26, 5: 661-681. 